\title{
Effect of thermal cycling on denture base and autopolymerizing reline resins
}

\author{
Cíntia de Souza SILVA ${ }^{1}$, Ana Lucia MACHADO², Carolina de Andrade Lima CHAVES ${ }^{3}$, Ana Cláudia PAVARINA², \\ Carlos Eduardo VERGANI ${ }^{2}$
}

\begin{abstract}
1- DDS, Department of Dental Materials and Prosthodontics, School of Dentistry Araraquara, UNESP - Univ. Estadual Paulista, Araraquara, SP, Brazil. 2- DDS, MSc, PhD, Professor, Department of Dental Materials and Prosthodontics, School of Dentistry Araraquara, UNESP - Univ. Estadual Paulista, Araraquara, SP, Brazil.

3- DDS, MSc, PhD student, Department of Dental Materials and Prosthodontics, School of Dentistry Araraquara, UNESP - Univ. Estadual Paulista, Araraquara, SP, Brazil.
\end{abstract}

Corresponding adress: Ana Lucia Machado - Rua Humaitá, 1680 - Araraquara - SP - Brazil - 14.801-903 - Phone: + $55163301-6410$ - Fax: + $55163301-6406$ e-mail: cucci@foar.unesp.br; almachado98@uol.com.br

Submitted: January 12, 2013 - Modified: March 19, 2013 - Accepted: April 5, 2013

\section{ABSTRACT}

\begin{abstract}
O bjective: This study evaluated the fracture toughness (FT) of denture base and autopolymerizing reline resins, with and without thermocycling $(T)$. Material and Methods: Specimens of each material (denture base acrylic resin - Lucitone 550 - L; autopolymerizing reline resins - Ufi Gel Hard-UH, Tokuyama Rebase II-TR, New TrulinerNT and Kooliner-K), were produced, notched and divided into two groups $(n=10)$ : CG (control group of autopolymerizing reline resins and L): FT tests were performed after polymerization; TG (thermocycled group): FT tests were performed after $\mathrm{T}\left(5^{\circ} \mathrm{C}\right.$ and $55^{\circ} \mathrm{C}$ for 5,000 cycles). Results: Results (MPa. $\mathrm{m}^{1 / 2}$ ) were analyzed by two-way ANOVA and Tukey's test $(p=0.05)$. L exhibited the highest FT mean values in both groups (CG - 2.33; TG 2.17). For the CG groups, NT showed the highest FT (1.64) among the autopolymerizing reline resins, and $\mathrm{K}$ the lowest (1.04). After $\mathrm{T}$, when the autopolymerizing reline resins were compared, a statistically significant difference in FT was found only between the NT (1.46) and TR (1.00). Conclusions: Thermocycling increased the FT of $\mathrm{K}$ and did not influence the FT of $\mathrm{L}, \mathrm{UH}, \mathrm{TR}$ and NT.
\end{abstract}

Key words: Acrylic resins. Denture bases. Thermic treatment.

\section{INTRODUCTION}

Poly (methyl methacrylate) (PMMA)-based polymers are the materials most commonly used for the construction of removable dentures due to their working characteristics, ease of manipulation, clinical serviceability and satisfactory aesthetics ${ }^{9,20}$. Another advantage offered by these polymers is the possibility of relining the denture intaglio surface to improve the fit to the supporting tissues due to changes that result from continued bone resorption. In this context, autopolymerizing reline resins can be an attractive alternative to heat-polymerized acrylic resins because they can be placed chair-side, are easier to apply, and no laboratory procedures are required ${ }^{25}$.

In the oral cavity, the denture prostheses are usually under conditions of thermal variations due to the ingestion of hot and cold liquids ${ }^{5,10,23}$. Such thermal cycling in a wet environment may cause degradation of the denture polymers ${ }^{1,17}$, and the heat stress may increase water sorption because of an extension of the distance between the polymer chains ${ }^{1}$. Absorbed water can act as a plasticizer and soften the denture, thus reducing the mechanical properties of the material ${ }^{1,9}$. Conversely, heating the acrylic resins may enhance further polymerization reactions ${ }^{27}$; consequently, an improvement in the mechanical properties can be expected ${ }^{27}$. Hence, the possible effect of thermal cycling on the mechanical properties of the acrylic resins must be considered since this factor may influence the performance of the relined removable prostheses.

Among the desirable properties of denture base and autopolymerizing reline resins is the fracture toughness which measures the sensitivity of the material to the presence of sharp notches (crack initiation $)^{28}$ such as frenal and incisal notches in 
maxillary dentures where stress concentration may occur $^{8}$. Denture fractures cause inconvenience, additional costs and social embarrassment to patients $^{8}$. Fracture toughness can be measured by using a fracture mechanics approach ${ }^{18}$ and may more accurately determine the likelihood of the fracture of denture polymers in clinical practice ${ }^{16}$.

Although several studies have evaluated the fracture toughness of denture base acrylic resins ${ }^{11,13,15,16,18,26,28}$, there is little information on the toughness of autopolymerizing reline resins ${ }^{12}$. In addition, the effect of thermal stresses on the toughness of denture base and autopolymerizing reline resins has not (to the authors' knowledge) been previously reported.

The aim of this study was to evaluate the effect of thermocycling on the fracture toughness of one denture base and four autopolymerizing reline resins. The null hypotheses were that there would be no differences in the fracture toughness among the acrylic resins evaluated and that this property would not be affected by thermocycling.

\section{MATERIAL AND METHODS}

One denture base acrylic resin (Lucitone 550) and four autopolymerizing reline resins (Ufi Gel Hard, Tokuyama Rebase II, New Truliner and Kooliner) were evaluated in this study. The product codes, batch numbers, manufacturers, compositions, powder/liquid proportions and polymerization cycles of the materials evaluated are listed in Figure 1.
Specimens from each material were produced using a stainless steel mold with a cavity (40 $\mathrm{mm} \times 8 \mathrm{~mm} \times 4 \mathrm{~mm})^{28}$. To fabricate the Lucitone 550 specimens, initially, the silicone impression material was adapted inside the stainless steel mold. The silicone patterns were then removed from the mold, placed between two glass slides and invested in Type IV stone using a conventional dentureprocessing flask. After the stone had set, the flask was opened and the silicone patterns were removed to create the stone molds. The Lucitone 550 heatpolymerized resin was then manipulated, packed into the stone mold, and polymerized in a water bath following the manufacturer's instructions (Figure 1). Then the flasks were removed from the water bath and bench cooled to room temperature before the specimens were removed. After polymerization, the specimens were finished with 320-grit silicon carbide paper to remove irregularities; then the accuracy of the dimensions was verified with a caliper. The specimens were then stored in water at $37^{\circ} \mathrm{C}$ for $48 \pm 2$ hours ${ }^{19}$.

To prepare the specimens of the autopolymerizing reline resins ( $\mathrm{UH}, \mathrm{TR}, \mathrm{NT}$ and $\mathrm{K})$, the stainless steel mold was placed on the center of a glass plate covered with an acetate sheet. The autopolymerizing reline resins were mixed according to the manufacturer's instructions, and placed into the mold spaces (40 $\mathrm{mm} \times 8 \mathrm{~mm} \times 4 \mathrm{~mm}$ ). A second acetate sheet was placed on top of the resin and another glass plate was placed on top of the acetate sheet. Light pressure was applied to expel excess material

\begin{tabular}{|c|c|c|c|c|c|c|}
\hline Product & Code & Manufacturer & $\begin{array}{l}\text { Powderl } \\
\text { liquid ratio }\end{array}$ & Composition & $\begin{array}{c}\text { Batch } \\
\text { number }\end{array}$ & $\begin{array}{l}\text { Polymerization } \\
\text { cycles }\end{array}$ \\
\hline Lucitone 550 & $\mathrm{~L}$ & $\begin{array}{l}\text { Dentsply Indústria } \\
\text { e Comércio Ltda., } \\
\text { Petrópolis, RJ, Brazil }\end{array}$ & $2.1 \mathrm{~g} / 1 \mathrm{ml}$ & $\begin{array}{l}\text { Powder - PMMA } \\
\text { Liquid - MMA and } \\
\text { EDGMA }\end{array}$ & $\begin{array}{l}P-87600 \\
L-91434\end{array}$ & $\begin{array}{l}90 \text { min at } 73^{\circ} \mathrm{C} \\
\text { and then } 100^{\circ} \mathrm{C} \\
\text { boiling water for } \\
30 \text { min }\end{array}$ \\
\hline Ufi Gel Hard & $\mathrm{UH}$ & $\begin{array}{c}\text { Voco, Cuxhaven, } \\
\text { Germany }\end{array}$ & $\begin{array}{c}2.12 \mathrm{~g} / 1.2 \\
\mathrm{~mL}\end{array}$ & $\begin{array}{c}\text { Powder - PEMA } \\
\text { Liquid - 1,6-HDMA }\end{array}$ & 631742 & $\begin{array}{c}8.5 \text { min at room } \\
\text { temperature }\end{array}$ \\
\hline $\begin{array}{l}\text { Tokuyama } \\
\text { Rebase II }\end{array}$ & TR & $\begin{array}{l}\text { Tokuyama Dental } \\
\text { Corp., Tokyo, Japan }\end{array}$ & $2.1 \mathrm{~g} / 1 \mathrm{~mL}$ & $\begin{array}{l}\text { Powder - PEMA } \\
\text { Liquid - AAEM and } \\
\text { 1,9-nonanediol } \\
\text { dimethacrylate }\end{array}$ & UF 65886 & $\begin{array}{l}5.5 \text { min at room } \\
\text { temperature }\end{array}$ \\
\hline New Truliner & NT & $\begin{array}{l}\text { The Bosworth Co., } \\
\text { Skokie, IL, USA }\end{array}$ & $1.34 \mathrm{~g} / 1 \mathrm{~mL}$ & $\begin{array}{c}\text { Powder - PEMA } \\
\text { Liquid - IBMA and } \\
\text { DBP }\end{array}$ & 0310-528 & $\begin{array}{l}20 \text { min at room } \\
\text { temperature }\end{array}$ \\
\hline Kooliner & $\mathrm{K}$ & $\begin{array}{c}\text { GC America Inc, Alsip, } \\
\text { IL, USA }\end{array}$ & $1.4 \mathrm{~g} / 1 \mathrm{~mL}$ & $\begin{array}{l}\text { Powder - PEMA } \\
\text { Liquid - IBMA }\end{array}$ & 805051 & $\begin{array}{l}10 \text { min at room } \\
\text { temperature }\end{array}$ \\
\hline
\end{tabular}

PMMA, poly (methyl methacrylate); MMA, (methyl methacrylate); EDGMA, (ethylene glycol dimethacrylate); PEMA, poly (ethyl methacrylate); 1,6-HDMA, 1,6-hexanediol dimethacrylate; AAEM - 2-acetoacetoxy (ethyl) methacrylate; IBMA, isobutyl methacrylate; DBP, di-n-butyl phthalate

Figure 1- Materials used in this study 
from the mold, and the materials were polymerized according to the manufacturers' instructions (Figure 1). After polymerization, any excess material was removed using silicon carbide paper (320-grit), and the dimensions were verified with a caliper.

For the fracture toughness measurements, the method used by Zappini, Kammann and Watcher ${ }^{28}$ (2003) and Puri, et al. ${ }^{26}$ (2008) was followed. The test requires a sharp-notched specimen loaded in a three-point bending configuration which is also known as the single edge-notched bend (SENB) method $^{28}$. Thus, a $0.5-\mathrm{mm}$-wide notch, $3.0 \mathrm{~mm}$ in length, was machined in the center of each specimen and then sharpened using a razor blade to extend the notch another 0.1 to $0.2 \mathrm{~mm}^{26}$. The specimens of each material $(n=20)$ were then divided into two groups: one control (CG) and one experimental (TG). For the UH, TR, NT and $\mathrm{K}$ autopolymerizing reline resins, the specimens were subjected to fracture toughness tests (GC group), or to the thermal cycling prior to the fracture toughness tests (TG group), within 30 min after polymerization. This time period was used since the patients will be wearing the relined denture bases soon after polymerization. For the $L$ denture base material, the specimens were subjected to fracture toughness tests (GC group), or to the thermal cycling prior to the fracture toughness tests (TG group), after storage in distilled water at $37 \pm 1^{\circ} \mathrm{C}$ for $48 \pm 2 \mathrm{~h}^{19}$. Thermal cycles were performed in a thermocycling machine (model MSCT-3, Marcelo Nucci - ME, São Carlos, SP, Brazil) and consisted of 5000 cycles at $5^{\circ} \mathrm{C}$ and $55^{\circ} \mathrm{C}$ with a 30 -second dwell time ${ }^{14}$.

Fracture toughness measurements were carried out in a universal testing machine (MTS 810, MTS Systems Corporation, Eden Prairie, MN, USA) in a three-point bending configuration at a cross-head speed of $1 \mathrm{~mm} / \mathrm{min}$ and a $32-\mathrm{mm}$ specimen test $\operatorname{span}^{26,28}$. The toughness test was carried out in a water bath at $37 \pm 1^{\circ} \mathrm{C}$.

The maximum stress intensity factor $\left(\mathrm{K}_{\mathrm{I}, \text { max }}\right)$ was calculated using the following formula ${ }^{28}: \mathrm{K}_{\mathrm{I}, \max }=f$ $\mathrm{P}_{\max } /\left(\mathrm{B} W^{1 / 2}\right)$, where $\mathrm{P}_{\max }$ is the maximum load, $\mathrm{B}$ is the specimen thickness, $W$ is the specimen width, and $f$ is a geometrical factor depending on the ratio $a / W . \mathrm{K}_{\mathrm{I}, \text { max }}$ was expressed in MPa. $\mathrm{m}^{1 / 2}$.

Data were analyzed using the two-way ANOVA and Tukey's tests $(p=0.05)$. The software package used for statistical analysis was the SPSS version 16.0 for Windows (Chicago, IL, USA).

\section{RESULTS}

The two-way ANOVA on the fracture toughness revealed a significant effect of material $(p<0.001)$ and material $\mathrm{x}$ thermocycling interaction $(p<0.001)$. ANOVA did not detect any significant effect of the main factor thermocycling ( $p=0.122)$.

Figure 2 shows the means and standard deviations for all materials and groups evaluated. For the control groups, the mean fracture toughness value of $L$ denture base acrylic resin was significantly higher than the values of the autopolymerizing reline resins $(p<0.001)$. Among the autopolymerizing reline resins, the NT material showed significantly higher $(p<0.001)$ mean fracture toughness than the UH and TR which did not differ from each other $(p=0.222)$. The $\mathrm{K}$ autopolymerizing reline resin exhibited the lowest fracture toughness mean value $(p<0.001)$.

For the thermocycled specimens, the denture base resin $\mathrm{L}$ showed a significantly higher mean than all autopolymerizing reline resins tested $(p<0.001)$. There was no significant difference between the NT and $\mathrm{UH}$ autopolymerizing reline resins $(p=0.821)$

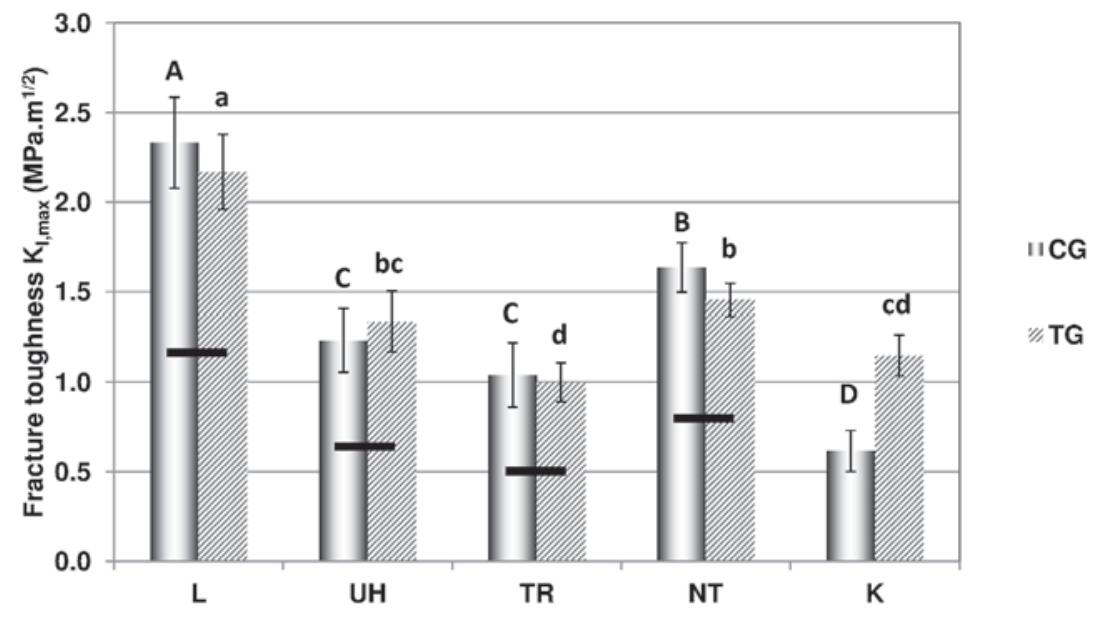

Figure 2- Means and standard deviations (SD) of fracture toughness $\mathrm{KI}$, max (MPa. $\mathrm{m}^{1 / 2}$ ) for the materials and groups evaluated. CG - control group. TG - thermocycled group. For the CG, means that are significantly different $(p<0.05)$ are indicated by different capital letters. For the TG, means that are significantly different $(p<0.05)$ are indicated by different small letters. For each material, connected bar denotes no significant difference between the CG and TG groups ( $p>0.05$ ) 
which in turn was not significantly different from the $\mathrm{K}(p=0.242)$. The difference between the $\mathrm{K}$ and TR materials was also not significant $(p=0.569)$.

Figure 2 illustrates that the fracture toughness of the $\mathrm{K}$ material showed a significant increase after thermocycling $(p=0.001)$. For the other materials evaluated ( $L, U H, T R$ and NT), thermocycling did not significantly affect the fracture toughness $(p=0.439$, $p=0.910, p=1.000$ and $p=0.305$, respectively).

\section{DISCUSSION}

Fracture toughness (the ability of a material to resist crack propagation,) is an important property for denture base and autopolymerizing reline resins, preventing or reducing the incidence of denture fracture, thus decreasing patient discomfort and unscheduled appointments for denture replacement or repair. The fracture toughness test was selected for this study because Zappini, Kammann and Watcher ${ }^{28}$ (2003), who evaluated seven heatpolymerized denture base resins, showed that this test may be more suitable for predicting the clinical performance of dental biomaterials than the impact test which is influenced by loading conditions and specimen geometry. The results demonstrated that the Lucitone 550 denture base acrylic resin exhibited the highest values of fracture toughness, in both the control and thermocycled groups, when compared with the autopolymerizing reline resins. Thus, the null hypothesis that the fracture toughness of the denture base and the autopolymerizing reline resins would be similar was rejected. Other investigators have also found that heat-polymerized denture base acrylic resins have higher mechanical properties than autopolymerizing acrylic resins, such as the autopolymerizing reline resins evaluated ${ }^{1,2,12,22}$. This result has been attributed to the higher temperature and longer polymerization time used for processing the heatpolymerized acrylic resins which decreases their residual monomer content ${ }^{7}$, and, consequently, improves their mechanical properties ${ }^{27}$. Mean toughness values for the Lucitone 550 were within the range reported in the literature for heatpolymerized denture base acrylic resins ${ }^{12,26,28}$.

In the control group, results also showed that the fracture toughness mean values of the Ufi Gel Hard and Tokuyama Rebase II materials were significantly lower than the values of the New Truliner autopolymerizing reline resin. One possible explanation for these findings could be their composition. According to the manufacturers, the Ufi Gel Hard and Tokuyama Rebase II materials contain high concentrations of the cross-linking agents 1.6-HDMA and 1.9-nonanediol dimethacrylate, respectively. Resins that are dimethacrylate-based result in a highly crosslinked polymer structure after polymerization, which undergoes brittle fracture ${ }^{4,21}$ due to the lack of molecular mobility and increased resistance against local plastic deformation. Resins composed primarily of monomethacrylates tend to produce lower crosslinking, and also lower strength values ${ }^{21}$. In this study, the Kooliner autopolymerizing reline resin is composed of the monofunctional monomer isobutyl methacrylate without a cross-linking agent which may account for the lower fracture toughness of this material. The higher level of residual monomer of the Kooliner $^{27}$ may also contribute to the findings since the unreacted monomer that remains within the polymerized material may compromise it's mechanical properties ${ }^{24,27}$. Although the Kooliner and New Truliner autopolymerizing reline resins have similar compositions, the fracture toughness of the New Truliner was significantly higher than the fracture toughness of the Kooliner. This result may be related to the plasticizer di- $n$-butyl phthalate $(8 \%)$ contained in the liquid of the New Truliner ${ }^{2,3}$ which provides flexibility to the material. It is likely that the crack propagated more slowly due to the ability of the New Truliner autopolymerizing reline resin to absorb energy through plastic deformation.

Over time, denture base and autopolymerizing reline resins are routinely exposed to a wide range of temperatures in a wet environment ${ }^{5,10,23}$, and therefore it is important to establish whether these changing oral temperatures affect their mechanical properties. Thus, it has been suggested that thermocycling should be part of the testing protocol for dental polymers. Thermocycling is an in vitro process where test materials are subjected to temperature extremes using water baths in an attempt to simulate conditions in the oral cavity. Hence, in this study, all materials were exposed to thermocycling $\left(5,000 \times 5^{\circ} \mathrm{C} / 55^{\circ} \mathrm{C}\right)$ in a water bath before testing. The hypothesis that the fracture toughness of the acrylic resins evaluated would not be affected by thermocycling was only partially accepted. While the fracture toughness of the materials Lucitone 550, Ufi Gel Hard, Tokuyama Rebase II and New Truliner did not change, and a significant increase in fracture toughness was observed for the Kooliner autopolymerizing reline resin. The thermal cycling procedure involved not only temperature changes, but also immersion in water baths. As mentioned before, the Ufi Gel Hard and Tokuyama Rebase II materials contain high concentrations of cross-linking agents. The Lucitone 550 denture base resin also contains the cross-linking agent ethylene glycol dimethacrylate (EDGMA). It has been reported that cross-linkage provides a sufficient number of bridges between linear macromolecules to form a three-dimensional network and thus decreases water sorption of the acrylic resins ${ }^{2,3}$. It has also been observed that the 
plasticizer molecules such as di-n-butyl phthalate contained in the New Truliner autopolymerizing reline resin can fill microvoids and thereby exclude the uptake of water ${ }^{2}$. In part, these aspects may explain why the fracture toughness of the materials Lucitone 550, Ufi Gel Hard, Tokuyama Rebase II and New Truliner was not affected when they were immersed in water during thermal cycling. For the Kooliner autopolymerizing reline resin, results from this study also showed that thermocycling resulted in a significant increase in fracture toughness. During thermocycling, the hot water may have accelerated the uptake of water which resulted in the plasticization of the polymer and decreased the mechanical properties. Conversely, the hot water may also have accelerated the release of degradation products and unreacted monomer molecules ${ }^{27}$, promoted further free-radical polymerization reactions and increased the degree of conversion ${ }^{27}$. Compared with the other materials evaluated, the Kooliner autopolymerizing reline resin presents significantly higher amount of available unreacted methacrylate units ${ }^{27}$. Moreover, Kooliner is a noncross-linked autopolymerizing reline resin which may have facilitated water sorption ${ }^{2,3}$. Absorbed water may act as a peculiar catalyst for the postpolymerization chemical reaction by increasing the probability of contact between groups that have not reacted to create chemical bonds ${ }^{6}$. Thus, it is likely that the release and post-polymerization phenomena were more extensive for this material and may have outweighed any plasticizing effect of the water. As a result, the fracture toughness of the Kooliner increased after thermocycling.

Mimicking one of the in vivo degradation factors involved (such as the thermal stresses which denture polymers will be exposed to in the oral cavity) is useful to disclose its effect on the general degradation process. Thus, in this in vitro study, the materials were subjected only to thermocycling. Based on these findings, it is possible that variations in oral temperature will have an overall positive effect on the fracture toughness. However, it should be noted that clinical conditions differ from the in vitro setting; for this reason, these findings must be carefully interpreted. Clinically, denture base and autopolymerizing reline resins will also be subjected to masticatory stresses; therefore, the effect of cyclic loading on the fracture toughness of these materials requires further investigation.

\section{CONCLUSIONS}

Within the limitations of this in vitro study, the following conclusions were reached:

1. The Lucitone 550 denture base acrylic resin displayed the highest mean fracture toughness values in both the control and thermocycled groups.
2. Among the autopolymerizing reline resins tested, the New Truliner material exhibited higher mean fracture toughness value than the Ufi Gel Hard, Tokuyama Rebase II and Kooliner materials in the control group. After thermocycling, the New Truliner showed a higher mean fracture toughness value than the Tokuyama Rebase II, while the Ufi Gel Hard and Kooliner materials did not differ from each other.

3. Thermocycling did not adversely affect the fracture toughness of the materials evaluated since the values either did not change (as occurred for the Lucitone 550, Ufi Gel Hard, Tokuyama Rebase II and New Truliner materials) or increased significantly (as observed for the Kooliner autopolymerizing reline resin).

\section{ACKNOWLEDGEMENTS}

Cíntia de Souza Silva was the recipient of a CNPq undergraduate scholarship (PIBIC-CNPq-UNESP).

\section{REFERENCES}

1- Archadian N, Kawano F, Ohguri T, Ichikawa T, Matsumoto N. Flexural strength of rebased denture polymers. J Oral Rehabil. 2000;27:690-6.

2- Arima T, Murata H, Hamada T. Properties of highly crosslinked autopolymerizing reline acrylic resins. J Prosthet Dent. 1995; 73:55-9.

3- Arima T, Murata H, Hamada T. Analysis of composition and structure of hard autopolymerizing reline resins. J Oral Rehabil. 1996;23:346-52.

4- Balkenhol M, Köhler $H$, Orbach K, Wöstmann B. Fracture toughness of cross-linked and non-cross-linked temporary crown and fixed partial denture materials. Dent Mater. 2009;25:917-28. 5- Barclay CW, Spence D, Laird WR. Intra-oral temperatures during function. J Oral Rehabil. 2005;32:886-94.

6- Bastioli C, Romano G, Migliaresi C. Water sorption and mechanical properties of dental composites. Biomaterials. 1990;11:219-23.

7- Bayraktar G, Guvener B, Bural C, Uresin Y. Influence of polymerization method, curing process, and length of time of storage in water on the residual methyl methacrylate content in dental acrylic resins. J Biomed Mater Res B Appl Biomater. 2006;76:340-5.

8- Cheng YY, Cheung WL, Chow TW. Strain analysis of maxillary complete denture with three-dimensional finite element method. J Prosthet Dent. 2010;103:309-18.

9- Durkan RK, Özdemir T, Pamir AD, Usanmaz A. Water absorption of two different denture base resins reinforced with dental fiber systems. J Appl Polym Sci. 2010;117:1750-3.

10- Ernst CP, Canbek K, Euler T, Willershausen B. In vivo validation of the historical in vitro thermocycling temperature range for dental materials testing. Clin Oral Invest. 2004;8:130-8.

11- Faltermeier A, Rosentritt M, Müssig D. Acrylic removable appliances: comparative evaluation of different postpolymerization methods. Am J Orthod Dentofacial Orthop. 2007;131:301.e16-22. 12- Finoti LS, Machado AL, Chaves C, Pavarina AC, Vergani CE. Effect of long-term water immersion on the fracture toughness of denture base and reline resins. Gerodontology. 2012;29:e858-64. 13- Franklin P, Wood DJ, Bubb NL. Reinforcement of poly (methyl methacrylate) denture base with glass flake. Dent Mater. 2005;21:365-70. 
14- Giampaolo ET, Jorge JH, Machado AL, Pavarina AC, Vergani CE. Effect of thermal cycling on microleakage between hard chairside relines and denture base acrylic resins. Gerodontology. 2010;28:121-6.

15- Hamouda IM, Ahmed SA. Effect of microwave disinfection on mechanical properties of denture base acrylic resin. J Mech Behav Biomed Mater. 2010;3:480-7.

16- Hamza T, Wee AG, Alapati S, Schricker SR. The fracture toughness of denture base material reinforced with different concentrations of POSS. J Macromol Sci Pure Appl Chem. 2004;41:897-906.

17- Hargreaves AS. The effects of cyclic stress on dental polymethylmethacrylate. I. Thermal and environmental fluctuation. J Oral Rehabil. 1983;10:75-85.

18- Hill RG, Bates JF, Lewis TT, Rees N. Fracture toughness of acrylic denture base. Biomaterials. 1983;4:112-20.

19- International Standards Organization. ISO 1567:1999/Amd 1:2003. Dentistry: denture base polymers. Amendment. Geneva: ISO; 2003.

20- Jagger D, Harrison A, Jagger R, Milward P. The effect of the addition of poly (methyl methacrylate) fibres on some properties of high strength heat-cured acrylic resin denture base material. J Oral Rehabil. 2003;30:231-5.

21- Knobloch LA, Kerby RE, Pulido T, Johnston WM. Relative fracture toughness of bis-acryl interim resin materials. J Prosthet Dent. 2011;106:118-25.
22- Lombardo CE, Canevarolo SV, Reis JM, Machado AL, Pavarina AC, Giampaolo ET, et al. Effect of microwave irradiation and water storage on the viscoelastic properties of denture base and reline acrylic resins. J Mech Behav Biomed Mater. 2012;5:53-61.

23- Palmer DS, Barco MT, Billy EJ. Temperature extremes produced orally by hot and cold liquids. J Prosthet Dent. 1992;67:325-7.

24- Patil PS, Chowdhary R, Mandokar RB. Effect of microwave postpolymerization treatment on residual monomer content and the flexural strength of autopolymerizing reline resin. Indian J Dent Res. 2009;20:293-7.

25- Polyzois GL, Lagouvardos PE, Frangou MJ. Flexural and bond strengths of relined denture polymers assessed by four-point bending tests and Weibull analysis. Gerodontology. 2012;29:e54352.

26- Puri G, Berzins DW, Dhuru VB, Raj PA, Rambhia SK, Dhir G, et al. Effect of phosphate group addition on the properties of denture base resins. J Prosthet Dent. 2008;100:302-8.

27- Urban VM, Machado AL, Vergani CE, Giampaolo ET, Pavarina AC, Almeida FG, et al. Effect of water-bath post-polymerization on the mechanical properties, degree of conversion, and leaching of residual compounds of hard chairside reline resins. Dent Mater. 2009;25:662-71.

28- Zappini G, Kammann A, Watcher W. Comparison of fracture tests of denture base materials. J Prosthet Dent. 2003;90:578-85. 